Revue d'histoire de l'Amérique française

BEVUE D.HISTOIRE DE L'AMÉRIQUE FRANÇAISE

\title{
Mid-America, vol. 31, number 3: 209-12. (july 1949). Published by Loyola University, Chicago 26, Illinois. JEROME V. JACOBSEN, "Jean Delanglez - In Memoriam"
}

\section{Lionel Groulx}

Volume 3, numéro 2, septembre 1949

URI : https://id.erudit.org/iderudit/801569ar

DOI : https://doi.org/10.7202/801569ar

Aller au sommaire du numéro

Éditeur(s)

Institut d'histoire de l'Amérique française

ISSN

0035-2357 (imprimé)

1492-1383 (numérique)

Découvrir la revue

Citer ce compte rendu

Groulx, L. (1949). Compte rendu de [Mid-America, vol. 31, number 3: 209-12. (july 1949). Published by Loyola University, Chicago 26, Illinois. JEROME V. JACOBSEN, "Jean Delanglez - In Memoriam"]. Revue d'histoire de l'Amérique française, 3(2), 286-286. https://doi.org/10.7202/801569ar d'utilisation que vous pouvez consulter en ligne.

https://apropos.erudit.org/fr/usagers/politique-dutilisation/ 
Mid-America, vol. 31, number 3: 209-12. (july 1949). Published by Loyola University, Chicago 26, Illinois.

Jerome V. Jacobsen, "Jean Delanglez - In Memoriam".

Un article ému et très instructif sur le très regretté historien. On y verra quelle circonstance amena le Père Delanglez qui songeait à écrire l'histoire des jésuites de l'Amazone, à se tourner plutôt vers le passé français du Mississipi. Le père Jacobsen nous dit la passion en quelque sorte sacrée de l'historien pour la vérité historique: "He considered each historical mistake a personal affront". Se sentant frappé au cœur, le Père Delanglez se mit à travailler avec une hâte fébrile; il devait succomber en plein labeur. Il venait de mettre la dernière main à l'édition française, de son Louis Jolliet. On nous apprend aussi que, trois jours avant sa mort il avait porté à la censure le manuscrit achevé d'un ouvrage sur Cadillac. Formons le vœu que cet ouvrage dont Mid-America a publié quelques chapitres, voie promptement le jour.

Lionel Groulx, ptre 